\title{
Experimental and Computational Study of the Thermodynamic Properties of Trivalent Cobalt Schiff Base Complexes with Cyclic Amines
}

\author{
Sheida Esmaielzadeh,* Leila Azimian and Zohreh Zare \\ Department of Chemistry, Darab branch, Islamic Azad University, Darab, I. R. Iran \\ * Corresponding author: E-mail: esmaielzadehsheida@yahoo.com
}

Received: 11-02-2016

\begin{abstract}
Some cobalt(III) complexes with a potentially tetradentate unsymmetrical NNOS Schiff base ligand have been synthesized and characterized using IR, ${ }^{1} \mathrm{HNMR}$, UV-Vis spectroscopy and elemental analysis. The equilibrium constants were measured spectrophotometrically for 1:1 adduct formation of the cobalt(III) complexes with some cyclic amines in acetonitrile as solvent at constant ionic strength $\left(I=0.1 \mathrm{M} \mathrm{NaClO}_{4}\right)$, and at various temperatures. In addition, the ground state geometries of the complexes were optimized using density functional theory (DFT) at B3LYP/6-311G** level. Binding energy, thermodynamic parameters, structural parameters and electronic structures of complexes are investigated. The theoretical investigations were done for comparing with the experimental results. Our comparison between the computational and experimental results revealed that the cobalt(III) complexation process is spontaneous, exothermic and entropically unfavorable.
\end{abstract}

Keywords: Cobalt complexes; Unsymmetrical Schiff base; Thermodynamic parameters; computational methods; experimental data.

\section{Introduction}

Synthetic oxygen carriers are of great interest as models to mimic oxygen caring metalloenzymes ${ }^{1}$ and oxygenases, such as hemoglobin and cytochrome P-450, ${ }^{2}$ which play important roles in the catalytic oxygenation mechanism of organic substrates. ${ }^{3}$

The Schiff base ligands and their complexes represent one of the most widely utilized classes of ligand in synthetic oxygen carrier compound. This usually arises from their structural similarity to those found in biological systems. ${ }^{4}$ The Co(III) Schiff base complexes have been extensively used to mimic cobalamin $\left(\mathrm{B}_{12}\right)$ coenzymes, ${ }^{5}$ dioxygen carriers and oxygen activators and for enantioselective reduction. ${ }^{6}$ These complexes are an important class of coordination compounds not only because being interesting $\mathrm{B}_{12}$ models but also due to their interesting magnetic properties, spectroscopic characteristics and catalytic aspects. ${ }^{7} \mathrm{Co}$ (III) complexes with the tetradentate Schiff base ligands have shown specific hypoxic radiosensitization and thermosensitization as well as antitumor activity in vivo. ${ }^{8}$ These cobalt complexes with two amines in axial positions have also been used as antimicrobial and antiviral agents. ${ }^{9}$
Many studies have been focused on the thermodynamic, kinetic, theoretical and catalytic aspects of this class of compounds. ${ }^{10,11}$ The thermodynamics and kinetics of complex formation, stability and mechanistic behavior of five-coordinate square-pyramidal or trigonal bipyramidal complexes of first-row transition metals have received significantly less attention although such five-coordinate complexes can exhibit significantly different ligand substitution behavior since they are, in principle, able to coordinate an additional nucleophile in the transition state. In contrast six-coordinate complexes undergo dissociative ligand substitution reaction. Thus, the study of their behavior is of fundamental importance to the understanding of complex formation and ligand substitution reaction in general.

Base on this experience and in order to contribute to a better understanding of the properties of five and six coordinated cobalt(III) Schiff base complexes, we report here the synthesis and characterization of some novel apparently five-coordinated complexes with apical tertiary phosphines as complex $\left[\mathrm{Co}(\mathrm{Chel})\left(\mathrm{PBu}_{3}\right)\right]^{+}$where Chel: methyl-2-\{N-[2-(acetone)ethylidynenitrilo]ethyl $\}$ amino1-cyclopentenedithiocarboxylate, (cdacacen), methyl-2- 
$\{N$-[2-(acetone)phenylidynenitrilo]ethyl $\}$ amino-1-cyclopentenedithiocarboxylate, (cdacPhen), methyl-2-\{N-[2(acetone)triflourolidynenitrilo]ethyl $\}$ amino-1-cyclopentenedithiocarboxylate, ( $\left.\mathrm{cdacCF}_{3} \mathrm{en}\right)$.

The thermodynamic parameters of five-coordinated complexes with cyclic amine groups at constant ionic strength and at various temperatures with the goal of evaluation of solvent effect and of the effect of equatorial ligand on electronic and steric properties have been studied. Also, we describe the results of theoretical calculations on the title compounds. The optimized structure, molecular orbital diagram and relative energies of cobalt(III) complexes have been calculated with density functional theory (DFT). A comparison between the calculated results (structure, formation constant, thermodynamic parameter) and experimental results are used to validate the conclusions.

\section{Experimental}

\section{1. Chemicals and Instruments}

Benzoylacetone, acetylacetone, 1,1,1-trifluoroacetone, 1,2-ethelendiamine, ammonia solution, carbon disulfide, dimethylsulfate, cyclopentanone, methanol, ethanol, acetonitrile, chloroform, hydrochloric acid, cobalt acetate tetrahydrate, tributylphoshine, imidazole, 2methyl imidazole, 2-ethyl imidazole, benzimidazole, sodium perchlorate monohydrate were purchased from Merck and Fluka. All chemicals and solvents were of analytical reagent grade and were used without any further purification. The solvents used for thermodynamic measurements were dried over molecular sieves $(3 \AA)$. The Schiff base ligands $\left(\mathrm{H}_{2}\right.$ cdacacen, $\mathrm{H}_{2}$ cdacPhen, $\mathrm{H}_{2} \mathrm{cdacCF}_{3} \mathrm{en}$ ) were prepared by following published procedures. ${ }^{19}$

Elemental analyses were performed on Termo Fininngan-Flash 1200 analyzer. The ${ }^{1} \mathrm{H}$ NMR spectra were obtained on a Bruker Avance DPX $400 \mathrm{MHz}$ spectrometer in DMSO- $d_{6}$ using TMS as an internal standard. Electronic spectra were recorded on a Perkin Elmer (LAMBDA 2) UV-Vis spectrophotometer with an appropriate quartz cell for complex solution. The temperature was controlled by electronic thermostate through the compartment surrounding the cell. The IR spectra of the compounds were carried out as $\mathrm{KBr}$ discs on a Shimadzu FTIR 8300 infrared spectrophotometer. The molar conductance ca. $10^{-3} \mathrm{M}$ solutions of the complexes in DMF were measured by means of a Jenway 4310 conductivity meter and a diptype cell with a platinized electrode.

\section{2. Synthesis of Ligands and Cobalt(III) Complexes}

The Schiff base ligands were prepared according to the literature by condensation of the half units methyl-2-
( $N$-2'-aminoethane)amino-1-cyclopentenedithiocarboxylate (Hcden) with acetylacetone, benzoylacetone and 1,1,1-trifluoro-2,4-pentanedione in methanol at room temperature and were purified from methanol/chloroform 2:1 (V:V). ${ }^{12}$ The novel $\left[\mathrm{Co}(\right.$ cdacacen $\left.)\left(\mathrm{PBu}_{3}\right)\right] \mathrm{ClO}_{4} \cdot \mathrm{H}_{2} \mathrm{O}$, $\left[\mathrm{Co}(\mathrm{cdacPhen})\left(\mathrm{PBu}_{3}\right)\right] \mathrm{ClO}_{4} \cdot \mathrm{H}_{2} \mathrm{O}$ and $\left[\mathrm{Co}\left(\mathrm{cdacCF}_{3}\right.\right.$ en $)$ $\left.\left(\mathrm{PBu}_{3}\right)\right] \mathrm{ClO}_{4} \cdot \mathrm{H}_{2} \mathrm{O}$ were synthesized as follow: To a refluxing solution of the unsymmetrical ligands $\left(\mathrm{H}_{2}\right.$ cdacacen, $\mathrm{H}_{2}$ cdacPhen, $\mathrm{H}_{2} \mathrm{CdacCF}_{3}$ en $)(0.1 \mathrm{mmol})$ in $10 \mathrm{~mL}$ of chloroform/methanol mixture (2:1) under $\mathrm{N}_{2}$ atmosphere, was added a solution of $\mathrm{Co}\left(\mathrm{CH}_{3} \mathrm{COO}\right)_{2} \cdot 4 \mathrm{H}_{2} \mathrm{O}(1 \mathrm{mmol})$ in methanol $(10 \mathrm{~mL})$ dropwisely. The deep brown or red solution of $\mathrm{Co}^{(\mathrm{II})}(\mathrm{L})$ complexes were precipitated, then the tributylphosphine $(0.1 \mathrm{mmol})$ was added and the reaction mixture was refluxed for 5-6 hours. The formed $\mathrm{Co}(\mathrm{II})$ complex was oxidized by blowing air into the solution for 2 hours, and the solution was filtered. An appropriate amount of sodium perchlorate $(0.1 \mathrm{mmol})$ was added to the filtrate. The resulting green crystals were formed after staying for $48 \mathrm{~h}$. They are collected by filtration and washed with portions of distilled water and methanol. The resulting green crystals were purified by recrystallization in $50: 50(\mathrm{~V} / \mathrm{V})$ methanol/ water, and were finally dried in vacuum at $30{ }^{\circ} \mathrm{C}$ for $24 \mathrm{~h}$.

Caution: Although no difficulties were experiences, cobalt(III) complexes were isolated as their perchlorates, and therefore, they should be handled as potentially explosive compounds.

\section{3. Thermodynamic Studies}

The adduct complexes were obtained from the reaction of the acceptors with the donors, according to equation (1)

$$
\begin{aligned}
& {\left[\mathrm{Co}(\mathrm{Chel})\left(\mathrm{PBu}_{3}\right)\right]^{+}+\text {Amine } \leftrightarrow} \\
& {\left[\mathrm{Co}(\mathrm{Chel})\left(\mathrm{PBu}_{3}\right)(\text { amine })\right]^{+}}
\end{aligned}
$$

where $\mathrm{Chel}=$ cdacacen, $\mathrm{cdacPhen}, \mathrm{cdacCF}_{3} \mathrm{en}$, and Amine = Im, 2-MeIm, 2-EtIm, BzIm.

The formation constant measurements were performed by spectrophotometric titration at $283,293,303$ and $313 \mathrm{~K}$. In a typical titration, $2.5 \mathrm{~mL}$ of solution (from each complex $\left(10^{-5}-10^{-4} \mathrm{M}\right)$ with a constant ionic strength $(I=$ $0.1 \mathrm{M}$; by adding sodium perchlorate in $\mathrm{CH}_{3} \mathrm{CN}$ ) was titrated with the amine solution in the same solvent. The titration was carried out by adding aliquots of the amine with a Hamilton microlitre syringe. The donor concentrations varied in the range of 1-10 folds in excess, which was low enough to avoid substitution of $\mathrm{PBu}_{3}$ by amine.

The absorption measurements were carried out at various wavelengths in 660-760 $\mathrm{nm}$ where the difference in absorption was the maximum after the equilibrium was assessed, since this is the optimal range for detecting the difference between the product and the substrate, while the donors show no absorption at those wavelengths. As 


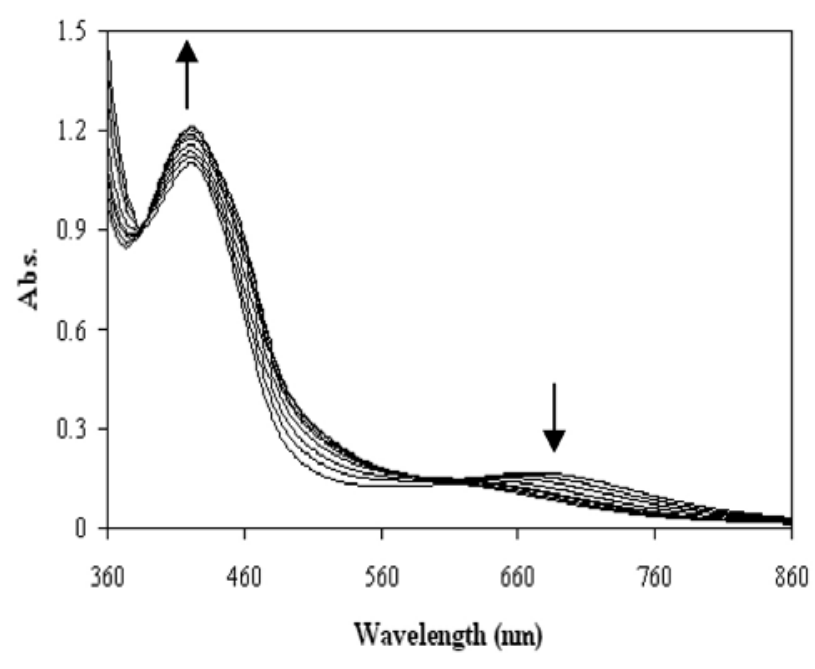

Figure 1. The spectral titration curve of $\left[\mathrm{Co}(\text { cdacacen })\left(\mathrm{PBu}_{3}\right)\right]^{+}$ with $\mathrm{Im}$ in $\mathrm{CH}_{3} \mathrm{CN}\left(I=0.1 \mathrm{M} \mathrm{ClO}_{4}, T=293 \mathrm{~K}\right)$.

an example, the variation of the electronic spectra for $\left[\mathrm{Co}(\right.$ cdacacen $\left.)\left(\mathrm{PBu}_{3}\right)\right] \mathrm{ClO}_{4} \cdot \mathrm{H}_{2} \mathrm{O}$ titrated with $\mathrm{Im}$ at $293 \mathrm{~K}$ in $\mathrm{CH}_{3} \mathrm{CN}$ is shown in Figure 1. The isosbestic points for this system show that there is only one reaction in equilibrium. The same are valid for the other systems.

\section{4. Computational Details}

The fully gas geometry optimization and the relative stability and molecular properties of the structures under investigation were carried out at density functional theory level ${ }^{13}$ using gradient technique ${ }^{14}$ and $6-311 \mathrm{G}^{* *}$ basis set. ${ }^{15}$ The DFT calculations were carried out with the B3LYP functional, in which Becke's nonlocal exchange ${ }^{16}$ and the Lee-Yang-Parr correlation functiona ${ }^{17}$ were applied. After the completion of the optimization the Hessian (second derivatives of the energy as a function of the nuclear coordinates) was calculated and checked for positive definiteness to assess whether the structures are true minima. ${ }^{13,18}$ The harmonic vibrational frequencies were then derived from the numerical values of these second derivatives and used to obtain the thermodynamic properties Gibbs free energy contributions at $283 \mathrm{~K}$. All the computation in the present study was performed using Gaussian03 for windows program. ${ }^{19}$

\section{Results and Discussion}

\section{1. Spectral Studies}

\section{1. 1. The Elemental Analyses and Molar Conductivity}

The cobalt(III) complexes were characterized by elemental analysis and molar conductivity (Table 1). The results of CHNS analysis are in good agreement with theoretical values. The analytical data show that the metal to ligand ratio is $1: 1$ in all complexes. This is supported by molar conductivity measurements of the complexes. All of the complexes are stable at room temperature in air and are insoluble in water and nonpolar solvents. However, they are soluble in an acetonitrile, methanol, ethanol, DMF and DMSO completely. The solution conductivity measurements were performed to establish the electrolyte type of the complexes. The molar conductivity at $10^{-3} \mathrm{M}$ for the complexes in DMF are in the range expected for their formulation as 1:1 electrolytes ${ }^{20}$ as shown in Table 1.

\section{1. 2. ${ }^{1} \mathrm{H}$ NMR Spectra}

To further confirm the bonding pattern in these complexes, ${ }^{1} \mathrm{H}$ NMR spectra of the cobalt(III) complexes were recorded in DMSO- $d_{6}$ using TMS as an internal standard and show that the cobalt in these complexes is low spin, the data was collected in Table 1 . The ${ }^{1} \mathrm{H}$ NMR spectra of the ligands show $\mathrm{OH}$ and $\mathrm{NH}$ protons signal at $\delta$ $12.39-12.45$ and $10.93-11.57$ ppm. Disappearance of these signals due to $-\mathrm{OH}$ and $-\mathrm{NH}$ protons in the spectra of the cobalt(III) complexes indicates the deprotonation of these groups which supports the coordination of ligand through oxygen and nitrogen atoms with cobalt atom. ${ }^{21} \mathrm{~A}$ singlet peak at 2.19-2.36 ppm with three proton integration has been assigned to the methyl group of the acetyl moiety. The proton chemical shifts for the coordinated $\mathrm{PBu}_{3}$ appear at $0.71-2.06 \mathrm{ppm}$ and are in agreement with the previous results observed for metal complexes of phosphine as axial ligand. ${ }^{22}$

\section{1. 3. Mode of Bonding and IR Spectra}

The IR spectra of the complexes were compared with those of the free ligands in order to determine the coordination sites that may be involved chelation. The broad bands in the range of $2947-3338 \mathrm{~cm}^{-1}$ is assigned to the stretching frequencies of the $v(\mathrm{OH})$ of the water molecules associated to the complexes. ${ }^{23}$ The weak bands at $2939-2966 \mathrm{~cm}^{-1}$ in the ligands are attributed to the stretching vibration of $\mathrm{CH}$ modes. In cobalt complexes containing $\mathrm{PBu}_{3}$ these bands were very strong, assignable to $\mathrm{C}-\mathrm{H}$ vibrations of $\mathrm{PBu}_{3} .{ }^{12}$ The $\mathrm{v}(\mathrm{C}=\mathrm{N})$ stretching vibration was found at $1600-1640 \mathrm{~cm}^{-1}$ in the free ligand ${ }^{12}$ and this band was shifted to lower wave numbers in the complexes, indicating the participation of the azomethine nitrogen in thecoordination. ${ }^{24}$

The medium sharp bands corresponding to $\mathrm{v}(\mathrm{C}-\mathrm{O})$ stretching vibration appeared at $1281 \mathrm{~cm}^{-1}$ and are shifted by about $25-30 \mathrm{~cm}^{-1}$ to lower energy region in the cobalt complexes compared to that of the free ligands. This phenomenon appears to be due to the coordination of oxygen (CO group) to the cobalt ion. ${ }^{25}$ The very strong, sharp and single bands at $1091-1093 \mathrm{~cm}^{-1}$ gives evidence for the presence of ionic perchlorate in all the complexes. ${ }^{26}$ Also, 
coordination of Shiff base ligand to the cobalt ion through the sulfur atom is expected to reduce electron density in the thiol bond and lower the $v(\mathrm{C}-\mathrm{S})$ absorption frequency in complexes. ${ }^{27}$

New bands in the range of $570-581 \mathrm{~cm}^{-1}$ and $427-436 \mathrm{~cm}^{-1}$ which are not present in the free Schiff base are due to $v(\mathrm{M}-\mathrm{O})$ and $v(\mathrm{M}-\mathrm{N})$ vibrations, ${ }^{25}$ and the appearance of these vibrations support the involvement of the nitrogen and oxygen atoms of the azomethine and $\mathrm{C}-\mathrm{O}$ groups in the complexation with the cobalt ion under investigations.

\section{1. 4. Electronic Absorption}

The UV-Vis spectrum of Schiff base ligands in $\mathrm{CH}_{3} \mathrm{CN}$ consists of a relatively intense band centered at $337 \mathrm{~nm}$ assigned to $\pi \rightarrow \pi^{*}$ transition and a second band at 362-365 nm corresponding to $\mathrm{n} \rightarrow \pi^{*}$ transition excitation. ${ }^{12}$ After complexation with $\mathrm{Co}(\mathrm{III})$ the band at 362-365 nm did not change appreciably in all the reactions studied. Moreover, an intense $\mathrm{d} \rightarrow \pi^{*}$ charge transfer band appears in the $670-700 \mathrm{~nm}$ region in the spectra of the five-coordinated complexes studied (Table 1). The $\mathrm{d}$ $\rightarrow \pi^{*}$ absorption band vanished to the adduct formation and the six-coordinated product species show a new absorption band at $450-470 \mathrm{~nm}$ region that is a shoulder ${ }^{28}$ (See Figure 1).

\section{2. Thermodynamic Parameters and the Formation Constant}

\section{2. 1. Thermodynamic Interpretations}

The formation constants of the various cobalt(III) unsymmetrical Schiff base complexes were calculated by Ketelaar's equation (2). ${ }^{29}$

$$
\begin{aligned}
\frac{\mathrm{C}_{\mathrm{A}}^{\circ} \mathrm{C}_{\mathrm{D}}^{\circ}}{\mathrm{A}-\mathrm{A}_{\mathrm{A}}^{\circ}-\mathrm{A}_{\mathrm{D}}^{\circ}}= & \frac{1}{\left(\varepsilon_{\mathrm{C}}-\varepsilon_{\mathrm{A}}-\varepsilon_{\mathrm{D}}\right)} \times \\
& \times\left[\frac{1}{\mathrm{~K}}+\left(\mathrm{C}_{\mathrm{A}}^{\circ}+\mathrm{C}_{\mathrm{D}}^{\circ}\right)\right]
\end{aligned}
$$

where $\mathrm{C}_{\mathrm{A}}^{\circ}$ and $\mathrm{C}_{\mathrm{D}}^{\circ}$ are the initial concentrations $\left(\mathrm{mol} \mathrm{L}^{-1}\right)$ of the acceptor and the donor, respectively. $\mathrm{A}$ is the optical density of the solution including the acceptor, the donor and the adduct complex, $\mathrm{A}_{\mathrm{A}}^{\circ}$ and $\mathrm{A}_{\mathrm{D}}^{\circ}$ are the optical densities of the pure acceptor and the pure donor in the solution of concentrations $\mathrm{A}_{\mathrm{A}}^{\circ}$ and $\mathrm{C}_{\mathrm{D}}^{\circ} ; \varepsilon_{\mathrm{C}}, \varepsilon_{\mathrm{A}}$ and $\varepsilon_{\mathrm{D}}$ are the molar extinction coefficients $\left(\mathrm{mol}^{-1} \mathrm{~L} \mathrm{~cm}^{-1}\right)$ of the complex, the acceptor and the donor, respectively. $\mathrm{K}$ is the formation constant of the formed complex and the cell optical path length is $1 \mathrm{~cm}$.

The linear plots of $\mathrm{P}=\mathrm{C}_{\mathrm{A}}^{\circ} \times \mathrm{C}_{\mathrm{D}}^{\circ} /\left(\mathrm{A}-\mathrm{A}_{\mathrm{A}}^{\circ}-\mathrm{A}_{\mathrm{D}}^{\circ}\right)$ vs. $\mathrm{C}=\mathrm{C}_{\mathrm{A}}^{\circ}+\mathrm{C}_{\mathrm{D}}^{\circ}$ ) should produce a straight line if only a $1: 1$ complex is formed; while a mixture of 1:1 and 1:2 or only

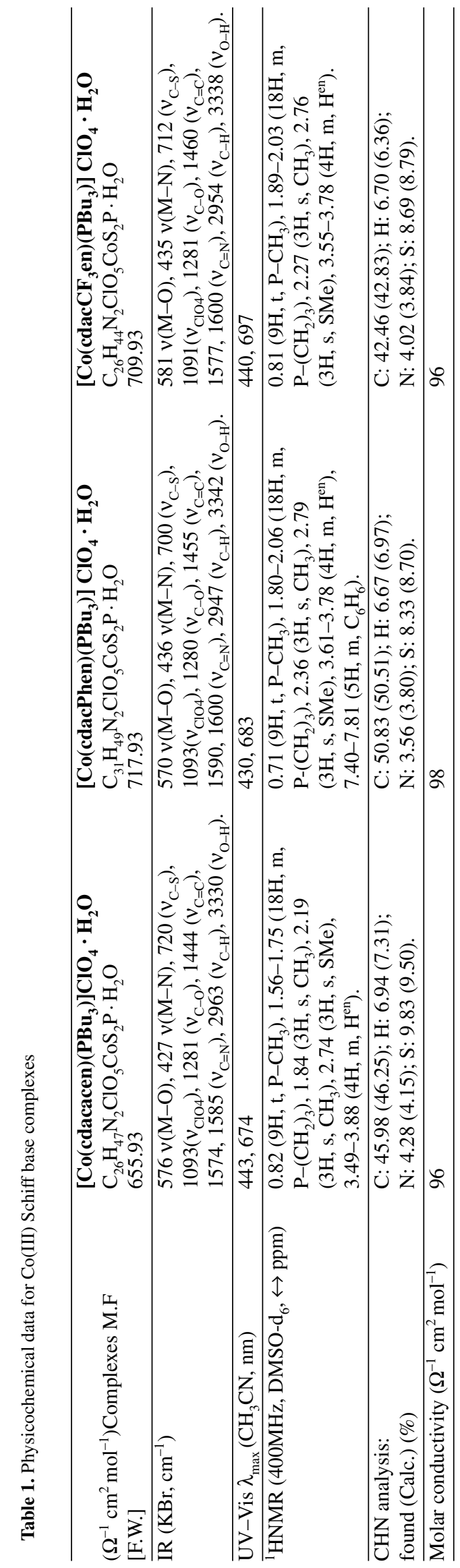




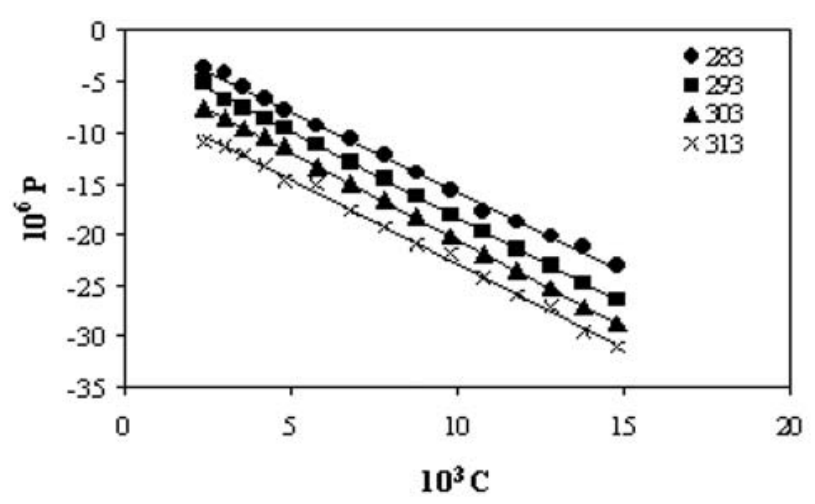

Figure 2. The Ketelaar plots of variable $\mathrm{P}$ vs. C for [Co(cdacacen $\left.)\left(\mathrm{PBu}_{3}\right)\right]^{+}$with $\mathrm{Im}$ at different temperatures $\left({ }^{\circ} \mathrm{C}\right)$ in $\mathrm{CH}_{3} \mathrm{CN}$, where, $\mathrm{P}=\mathrm{C}_{\mathrm{A}}^{\circ} \times \mathrm{C}_{\mathrm{D}}^{\circ} /\left(\mathrm{A}-\mathrm{A}_{\mathrm{A}}^{\circ}-\mathrm{A}_{\mathrm{D}}^{\circ}\right)$ and $\left.\mathrm{C}=\mathrm{C}_{\mathrm{A}}^{\circ}+\mathrm{C}_{\mathrm{D}}^{\circ}\right)$.

1:2 complexes in a system would lead to a curve. The formation constants of the studied cobalt(III) Schiff base complexes were calculated from the ratio of the slope to the intercept. The linear plot of $\mathrm{P} v s$. C for [Co(cdacacen) $\left.\left(\mathrm{PBu}_{3}\right)\right] \mathrm{ClO}_{4} \cdot \mathrm{H}_{2} \mathrm{O}$ titrated with $\mathrm{Im}$ at $283-313 \mathrm{~K}$ in $\mathrm{CH}_{3} \mathrm{CN}$ is shown in Figure 2 which signify that only a 1:1 adduct is formed. Similar plots are obtained for the other systems.

The thermodynamic parameters of the studied cobalt(III) unsymmetrical Schiff base complexes were calculated by using of the well-known van't Hoff equation (3):

$$
\ln K=-\Delta H^{\circ} / R T+\Delta S^{\circ} / R
$$

where $K$ is the formation constant, $R$ is the gas constant and $T$ is the temperature.

Thermodynamic parameters of the studied complexes were obtained from the linear plots of $\ln K v s$. 1/T. The linear plots for $\left[\mathrm{Co}(\right.$ cdacacen $\left.)\left(\mathrm{PBu}_{3}\right)\right] \mathrm{ClO}_{4} \cdot \mathrm{H}_{2} \mathrm{O}$ with $\mathrm{Im}$ are shown in Figure 3. The similar plots are obtained for other systems.

The values of $\Delta H^{\circ}$ and $\Delta S^{\circ}$ were obtained from the slope and the intercept, respectively. The $\Delta G^{\circ}$ of adduct formation was obtained according to equation (4) (Table 3).

$$
\Delta G^{\circ}=\Delta H^{\circ}-T \Delta S^{\circ}
$$

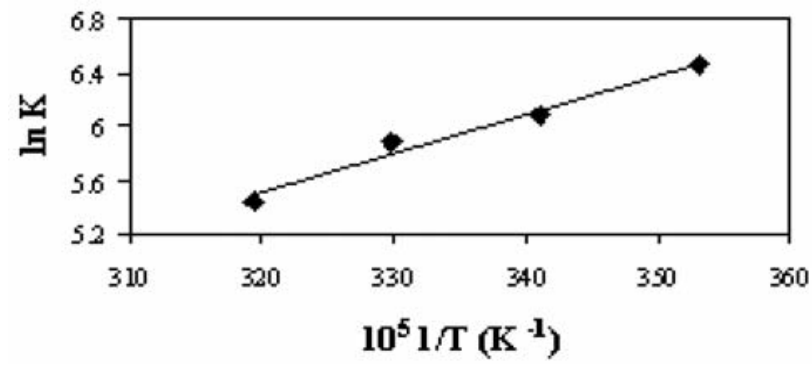

Figure 3. The plots of $\ln K$ vs. $1 / T$ for $\left[\mathrm{Co}(\text { cdacacen })\left(\mathrm{PBu}_{3}\right)\right]^{+}$with Im in $\mathrm{CH}_{3} \mathrm{CN}$.

\section{2. 2. The Equatorial Schiff Base Ligands on the Acceptor Property of Cobalt(III) Complexes Effect}

It is assumed that when cobalt ion is chelated in a macrocycle having delocalized electronic structure, the complex loses its transition character and might be kinetically labile. The extent to which this happens is likely to be strongly dependent on the structure of the Schiff base chelating system acting as acceptor of the donated charge. The equatorial ligands play important role in stability and reactivity of their complexes. This reactivity is affected by the steric and the electronic effects of the Schiff base ligands. For investigation of these properties of Schiff bases on the acceptor properties of cobalt(III) complexes, the thermodynamic study of these complexes with amines as donors in $\mathrm{CH}_{3} \mathrm{CN}$ were carried out. On the bases of the results (Table 2) the formation of adducts follow the sequence below:

$\left[\mathrm{Co}(\text { cdacacen })\left(\mathrm{PBu}_{3}\right)\right]^{+}>\left[\mathrm{Co}(\text { cdacPhen })\left(\mathrm{PBu}_{3}\right)\right]^{+}>$ $\left[\mathrm{Co}\left(\mathrm{CdacCF}_{3} \text { en }\right)\left(\mathrm{PBu}_{3}\right)\right]^{+}$

The electron $\pi$-acceptor qualities or donor ability of the substituents group on the ketones moiety on the Schiff base can influence the ability of the acceptor properties of the complexes. The $\mathrm{cdacCF}_{3}$ en ligand is stronger acceptor than cdacacen and cdacPhen, and the presence of phenyl withdrawing group causes the cdacPhen being a weaker Schiff base than cdacacen. So, the cobalt ion in [Co(cdac$\mathrm{CF}_{3}$ en $\left.)\left(\mathrm{PBu}_{3}\right)\right]^{+}$has more acceptor properties than the cobalt ion in other complexes. Accordingly, [Co(cdac$\mathrm{CF}_{3}$ en $\left.)\left(\mathrm{PBu}_{3}\right)\right]^{+}$forms more stable adduct with the water or solvent molecule (equation 5), in the six-coordinated complex a water or a polar solvent molecule occupies the sixth position, the interaction with the incoming donor is very weak ${ }^{30}$ and the reaction is shifted to the right by decreasing the electron donating power of Schiff base. Therefore, their tendency for the reaction with amines (as a donor) decrease, hence their formation constants with donors are lower. ${ }^{31}$

$$
\left[\mathrm{Co}(\mathrm{Chel})\left(\mathrm{PBu}_{3}\right)\right]^{+}+\mathrm{S} \leftrightarrow\left[\mathrm{Co}(\mathrm{Chel})\left(\mathrm{PBu}_{3}\right) \mathrm{S}\right]^{+}
$$

where $\mathrm{S}=\mathrm{H}_{2} \mathrm{O}$ or solvent molecule.

\section{2. 3. The cyclic Amine Donor Effect}

In this part of the report, four donors Im, 2-MeIm, 2-EtIm and BzIm have been examined as donors. We tried to investigate the steric and the electronic effects of these bases on their interaction with the newly synthesized complexes. The electron donating groups in the base increase the tendency of the organic bases toward the small acids like $\mathrm{H}^{+}$. On the other hand, the binding tendency of the organic bases toward the cobalt(III) centre is almost compatible with their steric rather than their basi- 
city character when the size of acids were increased..$^{32}$ Although the basic constants, $K_{\mathrm{b}}$, of the donor amines applied in this study are increased according to the trend: Im, 2-MeIm, 2-EtIm, BzIm have the $\mathrm{p} K_{\mathrm{a}}=6.73,7.52$, 7.86, 5.12, ${ }^{33}$ the formation constants for these bases with $\left[\mathrm{Co}(\text { cdacacen })\left(\mathrm{PBu}_{3}\right)\right]^{+},\left[\mathrm{Co}(\text { cdacPhen })\left(\mathrm{PBu}_{3}\right)\left(\mathrm{PBu}_{3}\right)\right]^{+}$ and $\left[\mathrm{Co}\left(\mathrm{cdacCF}_{3} \mathrm{en}\right)\left(\mathrm{PBu}_{3}\right)\right]^{+}$complexes were increased according to the following trend: $\mathrm{Im}>2$-MeIm $>2$-EtIm $>$ BzIm.

This trend shows that the steric factor is more important than electronic factor for each donor toward a given acceptor. When the steric hindrance of the entering ligand is increased, the formation constant is lower for all systems (See Table 2).

\section{2. 4. The Solvent Effect on Formation Constant}

To study the effects of the solvent on the equilibrium of five- and six-coordinated Schiff base cobalt complexes we determined the formation constants of $\left[\mathrm{Co}(\text { cdacacen })\left(\mathrm{PBu}_{3}\right)\right]^{+}$with $\mathrm{Im}$ in four solvents i.e. acetonitrile, THF, DMF and ethanol. The formation constant in solvent are dependent on many factors, one of them is
Gutmann donor number. ${ }^{34}$ The Gutmann donor number for solvents is shown in Table 3. It seems that the formation constants are decreased with increasing donor number of solvents (see Table 3). These results show that the five-coordinated complexes were found to be more stable in a solvent with higher donor number. In other words, a solvent with higher donor number can coordinate to a five-coordinated complex and stabilizes it toward a higher coordination number. Therefore, the trend of the influence of the solvent on the reactivity of the studied complex toward a given Im donor is: $\mathrm{CH}_{3} \mathrm{CN}>\mathrm{THF}>$ $\mathrm{DMF}>\mathrm{EtOH}$.

\section{2. 5. The Temperature Effect on Cobalt(III) Complex Formation}

The thermodynamic parameter such as $\Delta H^{\circ}$ and $\Delta S^{\circ}$ are dependent to temperature indirectly. In this work, equilibrium constants were carried out at various temperatures. Because of bond formation, by increasing the temperature, the formation constants were decreased.

In general, the $\Delta H^{\circ}$ value and its sign, is dependent on two factors: The solvation effect and the heat of adduct formation. ${ }^{35}$ According to the results (Table 4) the

Table 2. The formation constants, $\left(10^{-2} \times K_{\mathrm{f}}\left(\mathrm{M}^{-1}\right)\right)$, for $\mathrm{Co}(\mathrm{III})$ Schiff base complexes with various cyclic amines in $\mathrm{CH}_{3} \mathrm{CN}$ at different temperature $(\mathrm{K})$.

\begin{tabular}{|c|c|c|c|c|c|}
\hline Co(III) complexes & amine & 283 & 293 & 303 & 313 \\
\hline \multirow[t]{4}{*}[\mathrm{Co}(\mathrm{cdacCF}_{3}\text{en})(\mathrm{PBu}_{3})]{$^{+}$} & $\mathrm{Im}$ & $20.0 \pm 0.4$ & $18.7 \pm 0.8$ & $15.3 \pm 1.2$ & $12.1 \pm 0.3$ \\
\hline & 2-MeIm & $17.2 \pm 0.3$ & $16.4 \pm 0.2$ & $14.8 \pm 0.4$ & $11.2 \pm 0.8$ \\
\hline & 2-EtIm & $15.1 \pm 0.2$ & $12.7 \pm 0.1$ & $10.2 \pm 0.7$ & $7.7 \pm 0.4$ \\
\hline & BzIm & $8.5 \pm 1.4$ & $5.2 \pm 0.2$ & $3.6 \pm 0.3$ & $2.3 \pm 0.2$ \\
\hline \multirow[t]{4}{*}{$\overline{\left[\mathrm{Co}(\text { cdacPhen })\left(\mathrm{PBu}_{3}\right)\right]^{+}}$} & $\mathrm{Im}$ & $25.7 \pm 0.9$ & $20.7 \pm 1.1$ & $17.4 \pm 0.3$ & $14.7 \pm 1.5$ \\
\hline & 2-MeIm & $21.8 \pm 0.2$ & $18.5 \pm 0.7$ & $16.3 \pm 0.9$ & $13.6 \pm 0.4$ \\
\hline & 2-EtIm & $17.2 \pm 1.3$ & $15.6 \pm 0.8$ & $13.8 \pm 0.4$ & $12.1 \pm 0.2$ \\
\hline & BzIm & $12.7 \pm 0.4$ & $10.1 \pm 0.6$ & $7.2 \pm 0.2$ & $5.4 \pm 0.6$ \\
\hline \multirow{4}{*}[\mathrm{Co}(\text{cdacacen})(\mathrm{PBu}_{3})]{$^{+}$} & $\mathrm{Im}$ & $44.4 \pm 1.2$ & $32.1 \pm 0.4$ & $29.4 \pm 1.4$ & $24.0 \pm 0.1$ \\
\hline & 2-MeIm & $37.7 \pm 0.8$ & $28.9 \pm 0.2$ & $26.1 \pm 0.6$ & $21.4 \pm 0.7$ \\
\hline & 2-EtIm & $30.1 \pm 0.3$ & $26.8 \pm 0.5$ & $21.3 \pm 0.3$ & $18.9 \pm 1.1$ \\
\hline & BzIm & $19.8 \pm 1.7$ & $15.20 \pm 1.2$ & $12.1 \pm 0.6$ & $10.1 \pm 0.4$ \\
\hline
\end{tabular}

Table 3. The formation constants, $\left(10^{-2} \times K_{\mathrm{f}}\left(\mathrm{M}^{-1}\right)\right)$ and the thermodynamic parameter values, $\Delta H^{\circ}, \Delta S^{\circ}, \Delta G^{\circ}$ for $\left[\mathrm{Co}(\mathrm{cdacacen})\left(\mathrm{PBu}_{3}\right)\right] \mathrm{ClO} \mathrm{O}_{4} \cdot \mathrm{H}_{2} \mathrm{O}$ with $\mathrm{Im}$ in different solvents at different temperature $(\mathrm{K})$.

\begin{tabular}{lcrrr}
\hline & $\mathbf{C H}_{\mathbf{3}} \mathbf{C N}$ & THF & DMF & EtOH \\
\hline Donor No & 14.1 & 20.0 & 26.1 & 32 \\
283 & $44.4 \pm 1.2$ & $23.6 \pm 1.0$ & $13.7 \pm 0.9$ & $10.4 \pm 1.6$ \\
293 & $32.1 \pm 1.4$ & $15.8 \pm 0.5$ & $9.8 \pm 0.6$ & $8.7 \pm 1.5$ \\
303 & $29.4 \pm 1.4$ & $12.4 \pm 0.8$ & $7.7 \pm 0.8$ & $6.6 \pm 1.5$ \\
313 & $24.0 \pm 1.1$ & $10.2 \pm 1.1$ & $5.3 \pm 0.2$ & $4.8 \pm 1.4$ \\
$\Delta H^{\circ} /\left(\mathrm{kJ} \mathrm{mol}^{-1}\right)$ & $-56.9 \pm 3.2$ & $-39.6 \pm 4.6$ & $-27.0 \pm 1.8$ & $-14.7 \pm 1.2$ \\
$\Delta S^{\circ} /\left(\mathrm{J} \mathrm{K}^{-1} \mathrm{~mol}^{-1}\right)$ & $-96.6 \pm 4.5$ & $-50.6 \pm 6.8$ & $-23.6 \pm 2.7$ & $-6.5 \pm 3.8$ \\
$\Delta G^{\circ} /\left(\mathrm{kJ} \mathrm{mol}^{-1}\right)^{\mathrm{a}}$ & $-22.3 \pm 1.3$ & $-20.8 \pm 2.2$ & $-20.2 \pm 0.4$ & $-13.70 \pm 2.6$ \\
\hline
\end{tabular}

\footnotetext{
${ }^{\text {a }}$ at $T=303 \mathrm{~K}$
} 
Table 4. The experimental Thermodynamic parameter values, $\Delta H^{\circ}, \Delta S^{\circ}$ and $\Delta G^{\circ}$ for Co(III) Schiff base complexes with various cyclic amines in $\mathrm{CH}_{3} \mathrm{CN}$.

\begin{tabular}{|c|c|c|c|c|}
\hline Co (III) complexes & amine & $\Delta H^{\circ} /\left(\mathrm{kJmol}^{-1}\right)$ & $\Delta S^{\circ} /\left(\mathrm{J} \mathrm{K} \mathrm{K}^{-1} \mathrm{~mol}^{-1}\right)$ & $\Delta G^{\circ} /\left(\mathrm{kJmol}^{-1}\right)^{\mathrm{a}}$ \\
\hline \multirow{4}{*}[\mathrm{Co}(\mathrm{cdacCF}_{3}\mathrm{en})(\mathrm{PBu}_{3})]{$^{+}$} & $\mathrm{Im}$ & $-27.1 \pm 1.7$ & $-33.0 \pm 1.4$ & $-17.2 \pm 2.1$ \\
\hline & 2-MeIm & $-25.2 \pm 2.3$ & $-22.7 \pm 4.1$ & $-18.9 \pm 1.8$ \\
\hline & 2-EtIm & $-18.9 \pm 2.8$ & $-20.5 \pm 0.9$ & $-17.0 \pm 0.8$ \\
\hline & BzIm & $-15.3 \pm 2.9$ & $-9.3 \pm 2.7$ & $-12.5 \pm 1.1$ \\
\hline \multirow[t]{4}{*}[\mathrm{Co}(\mathrm{cdacPhen})(\mathrm{PBu}_{3})]{$^{+}$} & $\mathrm{Im}$ & $-43.5 \pm 6.8$ & $-77.7 \pm 3.2$ & $-20.3 \pm 2.5$ \\
\hline & 2-MeIm & $-33.3 \pm 1.7$ & $-52.7 \pm 5.1$ & $-17.6 \pm 3.1$ \\
\hline & 2-EtIm & $-27.1 \pm 1.0$ & $-33.0 \pm 0.7$ & $-17.2 \pm 3.9$ \\
\hline & BzIm & $-22.9 \pm 4.4$ & $-28.1 \pm 3.6$ & $-12.5 \pm 4.2$ \\
\hline \multirow{4}{*}[\mathrm{Co}(\text{cdacacen})(\mathrm{PBu}_{3})]{$^{+}$} & $\mathrm{Im}$ & $-56.9 \pm 3.2$ & $-96.6 \pm 4.5$ & $-22.3 \pm 2.5$ \\
\hline & 2-MeIm & $-40.4 \pm 3.8$ & $-62.7 \pm 4.1$ & $-21.4 \pm 2.1$ \\
\hline & 2-EtIm & $-38.6 \pm 2.8$ & $-60.6 \pm 4.3$ & $-19.0 \pm 3.3$ \\
\hline & BzIm & $-31.3 \pm 4.7$ & $-53.3 \pm 5.2$ & $-15.2 \pm 1.6$ \\
\hline
\end{tabular}

${ }^{\mathrm{a}}$ at $T=303 \mathrm{~K}$

enthalpy change values are negative because of bond formation in all reactions. The solvation effect for five- and six-coordinated complexes is not very different due to the same charge but it seems that the five-coordinated complex is better solvated because it is smaller and more polar than the six-coordinate complex. The solvation contribution for enthalpy change can be negative after the equilibrium. In all systems $\Delta H^{\circ}$ values are negative (Table 4).

The value of the $\Delta S^{\circ}$ and its sign are dependent on two factors: the difference in the number of the particles of the initial substances and the product complexes, and the liberation of the solvent molecules from the solvation shells. ${ }^{35}$ On the bases on first factor, the $n$ for all studied system is -1 . Concerning this factor the entropy decreases and its sign is negative. According to the second factor, the entropy change is increased, but the net entropy changes for all reactions are negative, which indicate that the both factors are important.

\section{3. Density Functional Analysis of the Cobalt(III) Complexes}

\section{3. 1. Thermodynamic Parameters With Theoretical Calculation}

Now, theoretical investigations have much applicability in the investigation of chemical reactions and identification of the chemical compounds. ${ }^{36,37}$ The effect of the molecular structures on the chemical reactivity has been object of great interest in several disciplines of chemistry. The quantum chemical calculations have been widely used to study the reaction mechanism and to interpret the experimental results as well as to solve chemical ambiguities. They could be considered as complementary to or replacement for experimental method. This is useful approach to investigate the mechanism of reaction in the molecule and its electronic structure level and electronic parameters can be obtained by means of theoretical calculations using the computational methodologies of quantum chemistry. The advancement in methodology and implementations has reached a point where predicted properties of reasonable accuracy can be obtained from density functional theory (DFT) calculations. In the literature the DFT has a great accuracy in reproducing the experimental values in geometry, kinetic and thermodynamic properties of a molecular system..$^{38,39}$

In order to have a better understanding of the thermodynamic properties of complexation between $\left[\mathrm{Co}(\mathrm{Chel})\left(\mathrm{PBu}_{3}\right)\right]^{+}$and some cyclic amines, it is useful to consider the stability energy, enthalpy and entropy changes to these reactions by DFT methods. As mentioned before, the geometry optimization of the five- and six-coordinated cobalt(III) complexes was performed using DFT methods with B3LYP functional and the 6-311G** basis set in the gas phase. The optimized structure of [Co(cdacacen $\left.)\left(\mathrm{PBu}_{3}\right)\right]^{+}$and $\left[\mathrm{Co}(\text { cdacacen })\left(\mathrm{PBu}_{3}\right)(\mathrm{Im})\right]^{+}$complex along with labeling of atoms is shown in Figure 4. The results of the computation reported in Tables 5 and 6 demonstrate the $H, S, G$ and $\Delta H, \Delta S, \Delta G$ thermodynamic parameters for each cobalt(III) complexes against the four cyclic amines.

On the basis of the theoretical results, the formations of the six-coordinated complexes follow the sequence below:

$\left[\mathrm{Co}\left(\mathrm{cdacCF}_{3} \text { en }\right)\left(\mathrm{PBu}_{3}\right)(\text { amine })\right]^{+}>[\mathrm{Co}($ cdacPhen $)$ $\left(\mathrm{PBu}_{3}\right)($ amine $\left.)\right]^{+}>\left[\mathrm{Co}(\text { cdacacen })\left(\mathrm{PBu}_{3}\right)(\text { amine })\right]^{+}$and for the amine donor are: $\mathrm{Im}>2$-MeIm $>2$-EtIm $>$ BzIm.

From these results, the following conclusions can be made:

i) The formation constant value $\left(\Delta E_{\mathrm{f}}\right)$ decreased from $(-105.42)-(-99.84) \mathrm{J} / \mathrm{mol}$ in $[\mathrm{Co}($ cdac$\mathrm{CF}_{3}$ en $)\left(\mathrm{PBu}_{3}\right)($ amine $\left.)\right]^{+}$to $(-42.17)-(-35.91)$ in $\left[\mathrm{Co}(\text { cdacacen })\left(\mathrm{PBu}_{3}\right)(\text { amine })\right]^{+}$, suggest that the trend of stability depend upon the donor or acceptor group on the ketones moiety. 

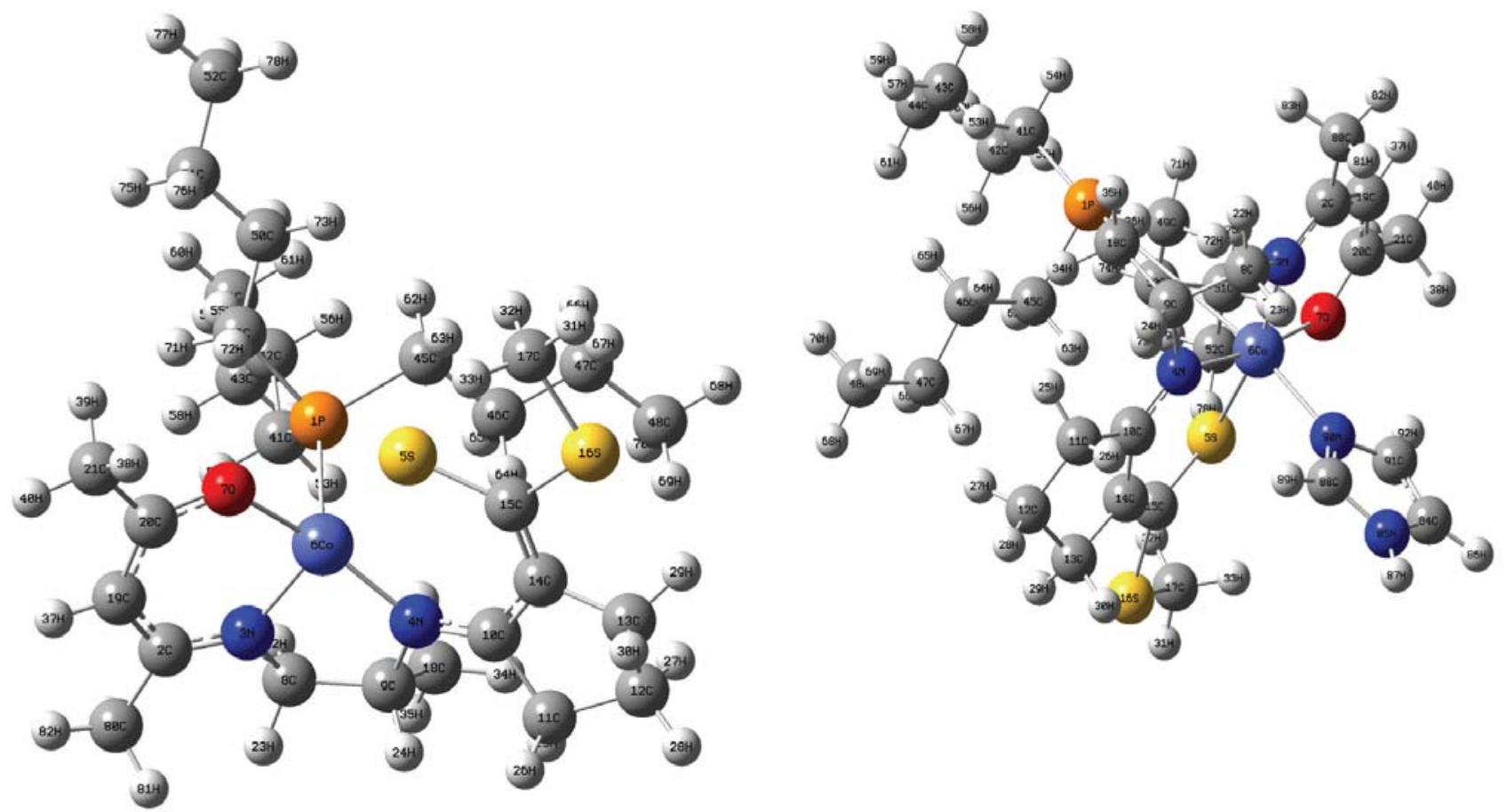

Figure 4. The optimized structures of $\left[\mathrm{Co}(\text { cdacacen })\left(\mathrm{PBu}_{3}\right)\right]^{+}$(left) and $\left[\mathrm{Co}(\text { cdacacen })\left(\mathrm{PBu}_{3}\right)(\mathrm{Im})\right]^{+}($right $)$complexes within numbering of atoms .

Table 5. The computational Thermodynamic parameter values, $H /$ (Hartree), $G /\left(\right.$ Hartree) and $S / \mathrm{J} \mathrm{K}^{-1} \mathrm{~mol}^{-1}$ for Co(III) Schiff base complexes, various cyclic amines and $\mathrm{Co}(\mathrm{III})$-amines in gas phase.

\begin{tabular}{|c|c|c|c|c|}
\hline $\begin{array}{c}\text { Thermodynamic } \\
\text { parameter } \\
\text { Compounds }\end{array}$ & & $\boldsymbol{H}$ & $G$ & $S$ \\
\hline$\left[\mathrm{Co}\left(\mathrm{cdacCF}_{3} \mathrm{en}\right)\left(\mathrm{PBu}_{3}\right)\right]^{+}$ & & -1568.1871 & -1568.3721 & 240.65 \\
\hline \multirow{4}{*}[\mathrm{Co}(\mathrm{cdacCF}_{3}\mathrm{en})(\mathrm{PBu}_{3})(\text{amine})]{$^{+}$} & $\mathrm{Co}(\mathrm{III})-\mathrm{Im}$ & -1894.7561 & -1894.9311 & 280.26 \\
\hline & $\mathrm{Co}(\mathrm{III})-2$-MeIm & -1894.7387 & -1894.9294 & 278.73 \\
\hline & $\mathrm{Co}(\mathrm{III})-2$-EtIm & -1894.7312 & -1894.9214 & 277.93 \\
\hline & Co(III) - BzIm & -1894.7068 & -1894.9197 & 275.14 \\
\hline \multirow[t]{4}{*}{ Amines } & $\operatorname{Im}$ & 326.5690 & 326.5590 & 80.16 \\
\hline & 2-MeIm & 326.5516 & 326.5573 & 79.41 \\
\hline & 2-EtIm & 326.5441 & 326.5493 & 79.10 \\
\hline & BzIm & 326.5197 & 326.5476 & 76.71 \\
\hline \multirow[t]{3}{*}[\mathrm{Co}(\mathrm{cdacPhen})(\mathrm{PBu}_{3})]{$^{+}$} & & -1426.6741 & -1426.8923 & 231.25 \\
\hline & $\mathrm{Co}(\mathrm{III})-\mathrm{Im}$ & -1674.8631 & -1674.9711 & 247.16 \\
\hline & Co(III) - 2-MeIm & -1674.8489 & -1674.9496 & 245.97 \\
\hline \multirow[t]{2}{*}{$\mathrm{Co}(\mathrm{cdacPhen})\left(\mathrm{PBu}_{3}\right)($ amine $\left.)\right]^{+}$} & Co(III) - 2-EtIm & -1674.8410 & -1674.9473 & 245.01 \\
\hline & Co(III) - BzIm & -1674.8390 & -1674.9426 & 240.43 \\
\hline \multirow[t]{4}{*}{ Amines } & $\operatorname{Im}$ & 248.1890 & 248.0788 & 80.16 \\
\hline & 2-MeIm & 248.1748 & 248.0573 & 79.41 \\
\hline & 2-EtIm & 248.1669 & 248.0550 & 79.10 \\
\hline & BzIm & 248.1649 & 248.0503 & 76.71 \\
\hline$\overline{\left[\mathrm{Co}(\mathrm{cdacPhen})\left(\mathrm{PBu}_{3}\right)\right]^{+}}$ & & -1106.3831 & -1106.9911 & 205.17 \\
\hline \multirow{4}{*}[\mathrm{Co}(\text{cdacacen})(\mathrm{PBu}_{3})(\text{amine})]{$^{+}$} & $\mathrm{Co}(\mathrm{III})-\mathrm{Im}$ & -1263.7491 & -1263.8998 & 226.86 \\
\hline & $\mathrm{Co}(\mathrm{III})-2$-MeIm & -1263.7126 & -1263.8590 & 221.11 \\
\hline & Co(III) - 2-EtIm & -1263.7111 & -1263.8573 & 220.19 \\
\hline & $\mathrm{Co}(\mathrm{III})$ - BzIm & -1263.6846 & -1263.8495 & 216.93 \\
\hline \multirow[t]{4}{*}{ Amines } & $\operatorname{Im}$ & 157.3660 & 156.9087 & 80.16 \\
\hline & 2-MeIm & 157.3295 & 156.9087 & 79.41 \\
\hline & 2-EtIm & 157.3280 & 156.8679 & 79.10 \\
\hline & BzIm & 157.3015 & 156.8662 & 76.71 \\
\hline
\end{tabular}


ii) The negative value of enthalpy changes $(\Delta H)$ for all studied system indicates that the process is exothermic and suggesting that the bond formation between $\mathrm{Co}^{(\mathrm{III})}$-amine are fairly strong. From the theoretical revalues, we can find that the trends of $\Delta H$ and $\Delta E_{\mathrm{f}}$ for six-coordinated cobalt(III) complex formation are different than the experimental values, due to difference of the studied molecular state. The isolated molecules in gas phase are considered in the theoretical calculations, while the experimental results are related to solution state.

iii) The entropy changes $(\Delta S)$ values for all reactions are negative, indicated that the entropy was responsible for the complexation process in all cases. The negative value of entropy also confirming that the complexes are formed spontaneously. ${ }^{40}$

iv) The Gibbs free energy $(\Delta G)$ in the ground state for all complexation reactions showed that the thermodynamic stability trend of studied cobalt(III) complexes was: $\left[\mathrm{Co}\left(\mathrm{cdacCF}_{3}\right.\right.$ en $)(\mathrm{PB}-$ $\left.\mathrm{u}_{3}\right)($ amine $\left.)\right]^{+}>\left[\mathrm{Co}(\text { cdacPhen })\left(\mathrm{PBu}_{3}\right)(\text { amine })\right]^{+}>$ $\left[\mathrm{Co}(\text { cdacacen })\left(\mathrm{PBu}_{3}\right) \text { (amine) }\right]^{+}$and for the amine donor was: $\mathrm{Im}>2$-MeIm $>$ 2-EtIm $>$ BzIm. According to $\Delta G$, these complexes take place at room temperature, so the most optimal conditions for stability of complexes relate to systems of unsaturated chemistry. ${ }^{41}$ In other hand, all the complex formation is the spontaneous reaction.

\section{3. 2. HOMO-LUMO Gap Energies and Chemical Hardness}

The highest occupied molecular orbital (HOMO) energies, the lowest unoccupied molecular orbital (LU$\mathrm{MO}$ ) energies and the energy gap for all five and six-coordinated cobalt(III) complexes were calculated with
B3LYP in 6-311G** basis set. The results are given in Table 7. The molecular HOMO/LUMO picture of the $\left[\mathrm{Co}(\text { cdacacen })\left(\mathrm{PBu}_{3}\right)(\mathrm{Im})\right]^{+}$complexes are depicted in Figure 5. In analogy to other $\left[\mathrm{Co}(\text { cdacacen })\left(\mathrm{PBu}_{3}\right)\right]^{+}(\mathrm{ac}-$ ceptor) - Im (donor) compounds the HOMO is mainly located on the Im moiety, whereas the LUMO is mostly locates on electron acceptor fragment.

The chemical hardness is useful to rationalize the relative stability and reactivity of chemical compounds. There are large HOMO- LUMO gap in the hard compounds and more stable and less reactive than soft compounds having small HOMO-LUMO gap. ${ }^{42}$ The definitions of universal concepts of molecular structure stability and reactivity can be provided using DFT method. For definition of hardness ç, following equation developed, ${ }^{43}$

$$
\eta=1 / 2(\mathrm{I}-\mathrm{A})
$$

where I and A are the vertical ionization energy and the vertical electron affinity respectively.

According to the Koopman theorem, ${ }^{44}$ the ionization energy and electron affinity can be equalized through $\mathrm{HO}-$ $\mathrm{MO}$ and LUMO orbital energies $\left(\mathrm{EA}=-E_{\mathrm{HOMO}}\right.$ and IP $=$ $\left.-E_{\mathrm{LUMO}}\right)$. So, the hardness corresponds to the gap between HOMO and LUMO orbital. Hence, the larger HOMOLUMO energy gaps the harder molecule.

$$
\eta=1 / 2\left(\mathrm{E}_{\mathrm{LUMO}}-\mathrm{E}_{\mathrm{HOMO}}\right)
$$

As seen from Table 7, The large HOMO-LUMO energy gaps for $\left[\mathrm{Co}\left(\mathrm{cdacCF}_{3} \mathrm{en}\right)\left(\mathrm{PBu}_{3}\right)(\text { amine })\right]^{+}$suggests that good stability and high chemical hardness for the titled complex. Indeed the chemical hardness of the $\left[\mathrm{Co}(\text { cdacacen })\left(\mathrm{PBu}_{3}\right)(\text { amine })\right]^{+}$complex is smallest, which indicates that these complexes is more unstable than the other studied cobalt(III) complexes in gas phase respectively.

Table 6. The computational Thermodynamic parameter values, $\Delta H^{\circ}, \Delta S^{\circ}$ and $\Delta G^{\circ}$ for Co(III) Schiff base complexes with various cyclic amines in

\begin{tabular}{|c|c|c|c|c|}
\hline$\overline{C o}$ (III) complexes & amine & $\Delta H^{\circ} /\left(\mathrm{kJmol}^{-1}\right)$ & $\Delta S^{\circ} /\left(\mathrm{J} \mathrm{K}^{-1} \mathrm{~mol}^{-1}\right)$ & $\Delta G^{\circ} /\left(\mathrm{kJmol}^{-1}\right)$ \\
\hline \multirow[t]{4}{*}[\mathrm{Co}(\mathrm{cdacCF}_{3}\text{en})(\mathrm{PBu}_{3})(\text{amine})]{$^{+}$} & $\mathrm{Im}$ & -28.1614 & -80.7311 & -30.5470 \\
\hline & 2-MeIm & -25.6829 & -79.7716 & -28.8412 \\
\hline & 2-EtIm & -25.2011 & -79.0016 & -28.7320 \\
\hline & BzIm & -17.7726 & -78.6413 & -27.9695 \\
\hline \multirow[t]{4}{*}[\mathrm{Co}(\mathrm{cdac}Phen)(\mathrm{PBu}_{3})(\text{amine})]{$^{+}$} & $\mathrm{Im}$ & -16.8187 & -56.0121 & -24.0891 \\
\hline & 2-MeIm & -14.9312 & -51.4311 & -21.9654 \\
\hline & 2-EtIm & -14.0925 & -50.9743 & -20.9717 \\
\hline & BzIm & -13.1790 & -48.2116 & -17.7614 \\
\hline \multirow[t]{4}{*}[\mathrm{Co}(\text{cdacacen})(\mathrm{PBu}_{3})(\text{amine})]{$^{+}$} & $\mathrm{Im}$ & -10.7277 & -42.1615 & -17.8417 \\
\hline & 2-MeIm & -8.6364 & -38.8050 & -14.1618 \\
\hline & 2-EtIm & -8.0012 & -36.1209 & -13.7893 \\
\hline & BzIm & -6.1713 & -32.9109 & -11.9817 \\
\hline
\end{tabular}
gas phase. 
a)

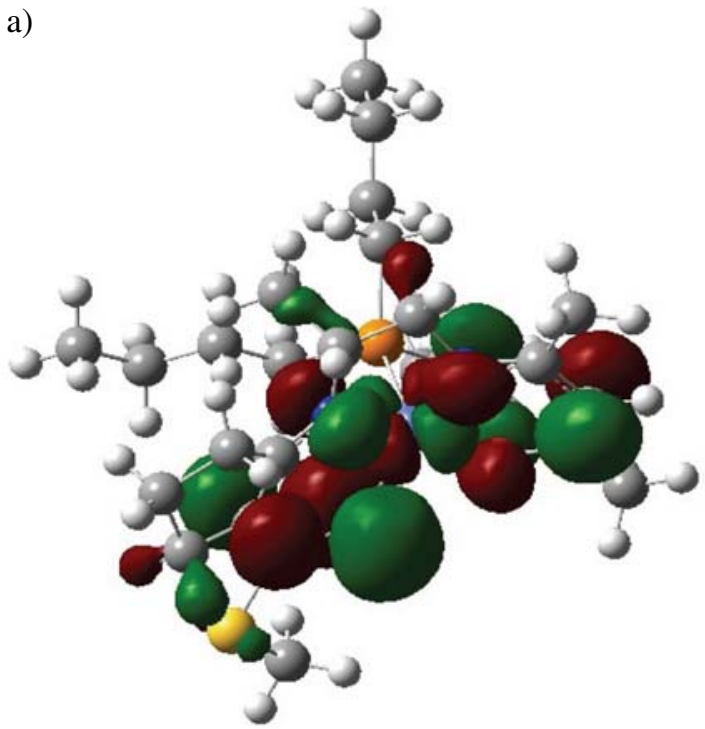

c)

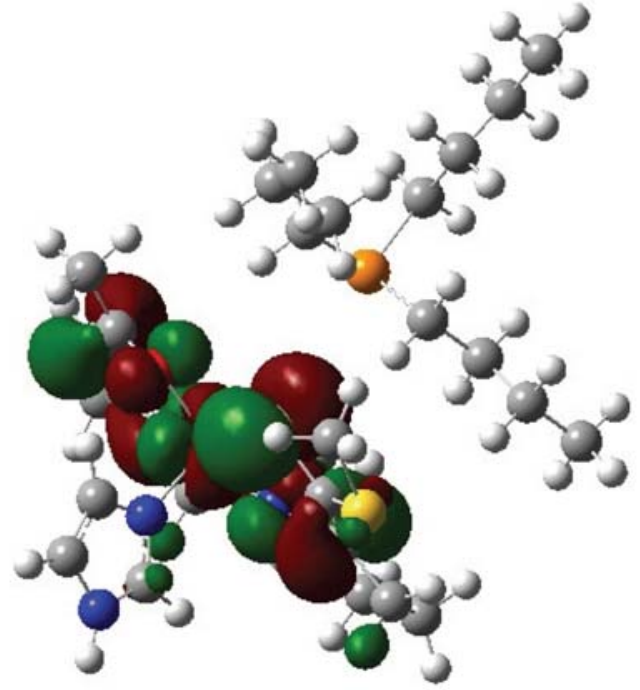

b)

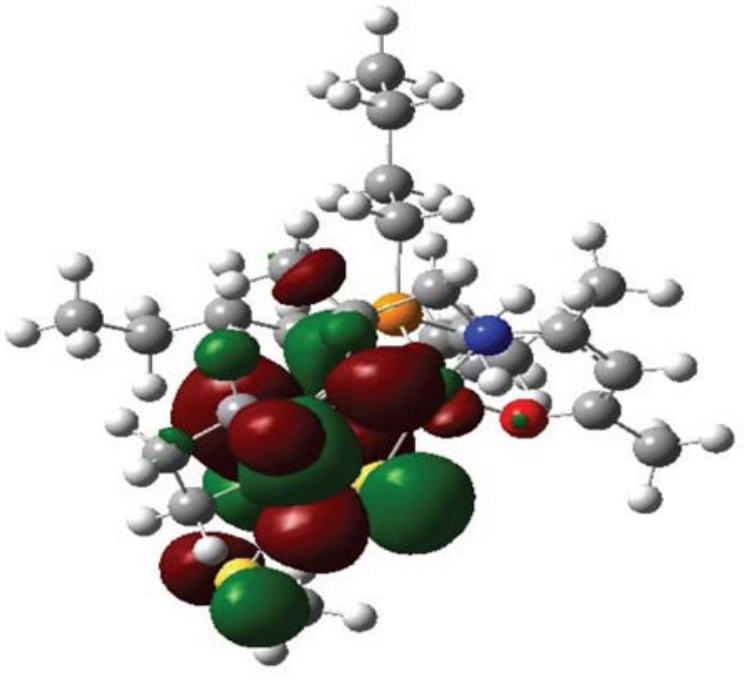

d)

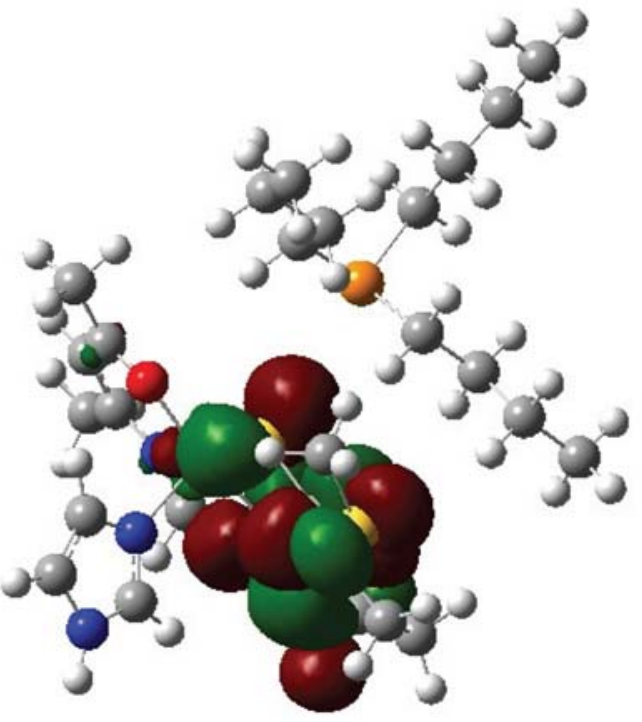

Figure 5. Molecular orbital surfaces for the HOMO and LUMO of the $\left[\mathrm{Co}(\text { cdacacen })\left(\mathrm{PBu}_{3}\right)\right]^{+}(\mathrm{a}, \mathrm{b})$ and $\left[\mathrm{Co}(\mathrm{cdacacen})\left(\mathrm{PBu}_{3}\right)(\mathrm{Im})\right]^{+}(\mathrm{c}, \mathrm{d}) \mathrm{compu}-$ ted at B3LYP/6-311 G** level.

Table 7. The computed electronic properties of Co(III) complexes with B3LYP/6-311G** level.

\begin{tabular}{|c|c|c|c|c|c|}
\hline Co (III) complexes & amine & HOMO/eV & LUMO/eV & gap/eV & Hardness \\
\hline \multirow[t]{4}{*}{$\overline{\left[\mathrm{Co}\left(\mathrm{cdacCF}_{3} \text { en }\right)\left(\mathrm{PBu}_{3}\right)(\text { amine })\right]^{+}}$} & $\mathrm{Im}$ & -0.264 & -0.073 & 0.191 & 0.095 \\
\hline & 2-MeIm & -0.238 & -0.056 & 0.182 & 0.091 \\
\hline & 2-EtIm & -0.221 & -0.042 & 0.179 & 0.089 \\
\hline & BzIm & -0.206 & -0.028 & 0.172 & 0.086 \\
\hline \multirow[t]{4}{*}[\mathrm{Co}(\mathrm{cdacPhen})(\mathrm{PBu}_{3})(\text{amine})]{$^{+}$} & Im & -0.198 & -0.056 & 0.142 & 0.071 \\
\hline & 2-MeIm & -0.183 & -0.044 & 0.139 & 0.069 \\
\hline & 2-EtIm & -0.176 & -0.039 & 0.137 & 0.068 \\
\hline & BzIm & -0.170 & -0.035 & 0.135 & 0.067 \\
\hline \multirow[t]{4}{*}[\mathrm{Co}(\text{cdacacen})(\mathrm{PBu}_{3})(\text{amine})]{$^{+}$} & $\mathrm{Im}$ & -0.170 & -0.038 & 0.132 & 0.066 \\
\hline & 2-MeIm & -0.156 & -0.029 & 0.127 & 0.063 \\
\hline & 2-EtIm & -0.152 & -0.029 & 0.123 & 0.061 \\
\hline & BzIm & -0.148 & -0.027 & 0.121 & 0.060 \\
\hline
\end{tabular}




\section{Conclusions}

In summary, the formation constants and the thermodynamic parameters for the complexation of five-coordinated cobalt(III) complexes as acceptors with imidazol and their derivatives as donors were determined experimentally based on spectrochemically and theoretically based on popular DFT methods including B3LYP and 6$311 \mathrm{G}^{* *}$ level of theory. The trend of the reactivity of titled cobalt(III) Schiff base complexes toward a given amine in experimental and computational studies is as follows: $\left[\mathrm{Co}(\text { cdacacen })\left(\mathrm{PBu}_{3}\right)\right]^{+}>\left[\mathrm{Co}(\text { cdacPhen })\left(\mathrm{PBu}_{3}\right)\right]^{+}>$ $\left[\mathrm{Co}\left(\mathrm{cdacCF}_{3} \mathrm{en}\right)\left(\mathrm{PBu}_{3}\right)\right]^{+}$and $\left[\mathrm{Co}\left(\mathrm{cdacCF}_{3} \mathrm{en}\right)\left(\mathrm{PBu}_{3}\right)\right]^{+}>$ $\left[\mathrm{Co}(\text { cdacPhen })\left(\mathrm{PBu}_{3}\right)\right]^{+}>\left[\mathrm{Co}(\text { cdacacen })\left(\mathrm{PBu}_{3}\right)\right]^{+}$. This difference was due to molecular state. The following binding trend of the donors toward a given cobalt(III) complexes is sequences $\operatorname{Im}>2$-MeIm $>2$-EtIm $>$ BzIm. The five-coordinated cobat(III) complexes was found to be more stable in solvent with higher donor number, So the trend of the reactivity of studied complexes toward donor according to the different solvents is as follows: $\mathrm{CH}_{3} \mathrm{CN}>$ THF $>$ DMF $>$ EtOH. The thermodynamic parameters as important values for stability index revealed high chemical reactivity of synthesized compound in chemical reaction. A comparison between the calculated results and experimental results are used to validate the conclusion.

\section{Acknowledgements}

We are grateful to Islamic Azad University, Darab branch Research Council for their financial support.

\section{References}

1. Y. Katayama, K. Hashimoto, H. Nakayama, H. Mino, M. Nojiri, T. Akiono, H. Nyunoya, M. Yohda, K. Takio, M. Odaka, J. Am. Chem. Soc. 2006, 128, 728-729. http://dx.doi.org/10.1021/ja057010q

2. B. Hu, Ch. Sun, Q. Deny, Z. Liu, J. Incl. Phenom. Macrocycl. Chem. 2013, 76, 345-352. http://dx.doi.org/10.1007/s10847-012-0205-x

3. M. Khorshidifar, H. Amiri Rudbari, B. Askari, M. Sahihi, M. Riahi Farsani, F. Jalilian, G. Bruno, Polyhedron 2015, 95, 1-13. http://dx.doi.org/10.1016/j.poly.2015.03.041

4. C. M. da Silva, D. L. da Silva, L. V. Modolo, R. B. Alves, M. A. de Resende, C. V. B. Martins, A. de Fatima, J. Adv. Res. 2011, 2, 1-8. http://dx.doi.org/10.1016/j.jare.2010.05.004

5. B. M. Alzoubi, G. Liehr, R. Eldik, Inorg. Chem. 2004, 43, 6093-6100. http://dx.doi.org/10.1021/ic049761j

6. Y. Zhang, W. Ruan, Y. Zhao, H. Wang, Z. Zhu, Polyhedron 2003, 22, 1535-1545.

http://dx.doi.org/10.1016/S0277-5387(03)00261-4

7. N. K. Chaudhary, P. Mishra, Am. J. Appl. Chem. 2014, 2, 19 26. http://dx.doi.org/10.11648/j.ajac.20140201.15
8. X. Rang, L. Wang, D. Cao, Y. Lin, J. Hao, Appl. Organomet. Chem. 2011, 25, 9-15.

http://dx.doi.org/10.1002/aoc. 1680

9. E. L. Chang, C. Simmers, D. A. Knight, Pharmaceuticals 2010, 3, 1711-1728. http://dx.doi.org/10.3390/ph3061711

10. T. C. Zeyrek. J. Korean. Chem. Soc. 2013, 57, 461-471.

11. R. Vafazadeh, S. Bidaki, Acta Chim. Slov. 2014, 61, 153- 160.

12. S. Esmaielzadeh, L. Azimian, K. Shekoohi, H. Esfandiari, M. Asadi, Z. Zare, A. R. Nejad, K. Mohammadi, Inorg. Chim. Acta 2013, 405, 155- 162.

http://dx.doi.org/10.1016/j.ica.2013.05.001

13. J. K. Labanowski, J. W. Andzelm, Density Functional Methods in Chemistry, Springer Verlag, New York, 1991. http://dx.doi.org/10.1007/978-1-4612-3136-3

14. J. Baker, J. Comput. Chem. 1986, 7, 385-395. http://dx.doi.org/10.1002/jcc.540070402

15. M. M. Francl, W. J. Pietro, W. J. Hehre, J. S. Binkle, M. S. Gordon, J. Chem. Phys. 1972, 77, 3645-3665.

16. A. D. Becke, Phys. Rev. A 1988, 38, 3098-3100. http://dx.doi.org/10.1103/PhysRevA.38.3098

17. C. Lee, W. Yang, R. G. Parr, Phys. Rev. B 1988, 37, 785-789. http://dx.doi.org/10.1103/PhysRevB.37.785

18. N. C. Handy, D. J. Tozer, G. J. Laming, C. W. Murrary, R. D. Amos, Isr. J. Chem. 1993, 33, 331-344. http://dx.doi.org/10.1002/ijch.199300040

19. M. J. Frisch, G. W. Trucks, H. B. Schlegel, G. E. Scuseria, M. A. Robb, J. R. Cheeseman, J. A. Montgomery, J. T. Vreven, K. N. Kudin, J. C. Burant, J. M. Millam, S. S. Iyengar, J. Tomasi, V. Barone, B. Mennucci, M. Cossi, G. Scalmani, N. Rega, G. A. Petersson, H. Nakatsuji, M. Hada, M. Ehara, K. Toyota, R. Fukuda, J. Hasegawa, M. Ishida, T. Nakajima, Y. Honda, O. Kitao, H. Nakai, M. Klene, X. Li, J. E. Knox, H. P. Hratchian, J. B. Cross, C. Adamo, J. Jaramillo, R. Gomperts, R. E. Stratmann, O. Yazyev, A. J. Austin, R. Cammi, C. Pomelli, J. W. Ochterski, P. Y. Ayala, K. Morokuma, G. A. Voth, P. Salvador, J. J. Dannenberg, V. G. Zakrzewski, S. Dapprich, A. D. Daniels, M. C. Strain, O. Farkas, D. K. Malick, A. D. Rabuck, K. Raghavachari, J. B. Foresman, J.V. Ortiz, Q. Cui, A. G. Baboul, S. Clifford, J. Cioslowski, B. B. Stefanov, G. Liu, A. Liashenko, P. Piskorz, I. Komaromi, R. L. Martin, D. J. Fox, T. Keith, M. A. Al-Laham, C. Y. Peng, A. Nanayakkara, M. Challacombe, P. M. W. Gill, B. Johnson, W. Chen, M. W. Wong, C. Gonzalez, J. A. Pople, Gaussian, Inc., Pittsburgh PA, 2003.

20. Z. Szafran, R. M. Pike, M. M. Singh, Microscale Inorganic Chemistry, Willey, New York, 1991.

21. R. Vafazadeh, M. Kashfi, Bull. Korean. Chem. Soc. 2007, 28, 1227-1230. http://dx.doi.org/10.5012/bkcs.2007.28.7.1227

22. M. Asadi, Z. Asadi, Trans. Met. Chem. 2007, 32, 387-392. http://dx.doi.org/10.1007/s11243-007-0188-4

23. A. A. Emara, Spectrochim. Acta, Part A. Mol. Biomol. Spect. 2010, 77, 117-125. http://dx.doi.org/10.1016/j.saa.2010.04.036

24. M. A. Ali, A. H. Mirza, M. H. S. A. Hamid, N. Aminath, P. V. Bernhardt, Polyhedron 2012, 47, 79-86. 
http://dx.doi.org/10.1016/j.poly.2012.08.024

25. D. Sakthialatha, R. Rajavel, J. Chem. Pharma. Res. 2013, 5, 57-63.

26. P. Bhowmik, M. G. B. Drew, S. Chattopadhyay, Inorg. Chim. Acta 2011, 366, 62-67. http://dx.doi.org/10.1016/j.ica.2010.10.010

27. M. A. Ali, A. H. Mirza, W. Y. Ting, M. H. S. A. Hamid, P. V. Bernhardt, R. J. Butcher, Polyhedron 2012, 48, 167-173. http://dx.doi.org/10.1016/j.poly.2012.08.069

28. M. Asadi, S. Esmaielzadeh, K. Mohammadi, Acta Chim. Slov. 2009, 56, 927-935. http://dx.doi.org/10.1002/recl.19520711108

29. J. A. A. Ketelaar, C. Van De Stolpe, A. Coulsit, W. Dz Cubes, Rec. Trav. Chim. 1952, 71, 1104-1114.

30. G. Tauzher, G. Mestroni, A. Puxeddu, R. Costanzo, G. Costa, J. Chem. Soc. A 1971, 2504-2507. http://dx.doi.org/10.1039/j19710002504

31. M. Asadi, A. H. Kianfar, S. Torabi, K. Mohammadi, J. Chem. Thermodynamics 2008, 40, 523-528. http://dx.doi.org/10.1016/j.jct.2007.08.003

32. G. L Miessler, D. A.Tarr, Inorganic Chemistry, PrenticeHall, New Jersy; 1991.

33. K. Hofmann, The Chemistry of Hetero Cyclic Compounds: Imidazole and Its Derivatives, Part I, Interscience Publisher, Inc., New York, 1953. http://dx.doi.org/10.1002/9780470186541

34. Y. Marcus, The Properties of Solvent, John Wiley \& Sons, New York, 1999.

35. S. Abrland, Helv. Chim. Acta 1967, 50, 306-318. http://dx.doi.org/10.1002/hlca.19670500138

36. M. Najafi, D. Farmanzadeh, E. Klein, M. Zahedi, Acta Chim. Slov. 2013, 60, 43-55.

37. S. Esmaielzadeh, L. Azimian, K. Shekoohi, K. Mohammadi, Spectrochim. Acta, Part A. Mol. Biomol. Spect. 2014, 133, 579-590. http://dx.doi.org/10.1016/j.saa.2014.05.095

38. H. P. Ebrahimi, J. S. Hadi, Z. A. Abdulnabi, Z. Bolandnazar, Spectrochim. Acta, Part A. Mol. Biomol. Spect. 2014, 117, 485-492. http://dx.doi.org/10.1016/j.saa.2013.08.044

39. R. D. Chirico, W. V. Steele, A. F. Kazakov, J. Chem. Thermodynamics 2015, 86, 106-115. http://dx.doi.org/10.1016/j.jct.2015.02.008

40. P. Mishra. Int. J. Pharma. Sci. Rev. Res. 2010, 2, 87-97.

41. M. Oftadeh, M. Moghadary, M. Soleimannejad, A. Semnani, Acta. Chim. Slov. 2013, 60, 95-104.

42. N. Özbek, G. Kavak, Y. Özcan, S. Ide, N. Karacan, J. Mol. Struct. 2009, 919, 154-159. http://dx.doi.org/10.1016/j.molstruc.2008.09.010

43. R. G. Pearson, J. Chem. Ed. 1987, 64, 561-567. http://dx.doi.org/10.1021/ed064p561

44. T. Koopmans, Polyhedron 1933, 1, 104-113.

\section{Povzetek}

Sintetizirali smo nekaj kobaltovih(III) kompleksov s potencialno štirivezno nesimetrično NNOS Schiffovo bazo kot ligandom ter jih okarakterizirali z uporabo IR, ${ }^{1} \mathrm{HNMR}$ in UV-Vis spektroskopije ter elementne analize. Ravnotežne konstante so bile določene spektrofotometrično kot 1:1 adukt, ki nastane med kobaltovim(III) kompleksom z nekaterimi cikličnimi amini v acetonitrilu kot topilu pri konstantni ionski moči $\left(I=0.1 \mathrm{M} \mathrm{NaClO}_{4}\right)$ ter pri različnih temperaturah. Nadalje, geometrije osnovnega stanja so bile izračunane z uporabo teorije gostotnostnega funkcionala (DFT) na B3LYP/6$311 \mathrm{G}^{* *}$ nivoju. Vezne energije, termodinamski parametri, strukturni parametri in elektronske strukture so bile raziskane. Teoretično proučevanje je bilo izvedeno za primerjavo z eksperimentalnimi podatki. Naša primerjava med računskimi in eksperimentalnimi rezultati razkriva, da je kompleksiranje kobaltovega(III) iona spontan, eksotermen proces, ki je entropijsko nezaželen. 